\title{
Elevated Clozapine Level Following Acute Infection in a Patient with Schizophrenia: a Case Report
}

\author{
JYK Poon, DYY Tang, BWM Siu, SH Lui
}

\begin{abstract}
We describe a 58-year-old Chinese man with schizophrenia who presented with an elevated clozapine level suspected to be related to acute infection.
\end{abstract}

Key words: Clozapine; Infections; Schizophrenia

Johannes YK Poon, Castle Peak Hospital, Hong Kong

Dorothy YY Tang, Castle Peak Hospital, Hong Kong

Bonnie WM Siu, Castle Peak Hospital, Hong Kong

SH Lui, Castle Peak Hospital, Hong Kong

Address for correspondence: Dr Johannes YK Poon, Castle Peak Hospital, Hong Kong.

Email:pyk449@ha.org.hk

Submitted: 7 August 2019; Accepted: 14 April 2020

\section{Introduction}

Clozapine is widely prescribed for treatment-resistant schizophrenia, but monitoring of clozapine plasma level is uncommon among local practitioners. Although clozapine toxicity is a constellation of severe adverse effects of clozapine, the plasma level beyond which it occurs remains unclear. ${ }^{1}$ There is evidence linking infections to elevated clozapine levels and potentially toxicity. ${ }^{2}$ We describe a Chinese man with schizophrenia who presented with an elevated clozapine level suspected to be related to acute infection.

\section{Case Presentation}

On 13 January 2019, a 58-year-old Chinese man with treatment-resistant schizophrenia who had been admitted to Castle Peak Hospital since July 2018 developed a fever of $37.8^{\circ} \mathrm{C}$, dysuria, and left loin pain. Since 12 November 2018 , he had taken clozapine and gradually increased to $300 \mathrm{mg}$ twice daily. Augmentation with amisulpride and sulpiride was tried, but limited benefits were noted. On 17 December 2018, improvement was observed with risperidone $3 \mathrm{mg}$ at night. On 24 December, sodium valproate was increased to $1100 \mathrm{mg}$ at night as prophylaxis for seizure and irritability. The patient was also taking aspirin, terazosin, potassium chloride sustained release, famotidine, benzhexol, and a number of laxatives. The patient was stable mentally and physically.

Physical examination revealed left loin tenderness.
His white cell count was $16.6 \times 10^{9} / \mathrm{L}$ (reference range, $\left.3.9-10.7 \times 10^{9} / \mathrm{L}\right)$, with elevated neutrophil and monocyte levels (Table 1). Fever subsided with paracetamol within a day. Dysuria and left loin pain continued for a few days and then resolved without the need for antibiotics. Urine culture result was negative, and radiography showed no evidence of stones in the urinary system. Liver and renal function test results were grossly normal, except for mild hyponatraemia, which was corrected by taking sodium chloride tablets for 2 days.

In late January 2019, the patient started to appear sedated with bilateral hand tremor. The sedation and extrapyramidal adverse effects became progressively severe. By mid-February 2019, he showed slow response, severe hypersalivation, tremor, rigidity, and worsening of long-standing constipation. Blood pressure and pulse rate were within normal range. He remained fully oriented and showed no deterioration of psychotic symptoms. On 1 March 2019, his white cell count remained high, with elevated neutrophil and monocyte levels (Table 1). There had been no change in medications, except for an increase in benzhexol for relief of extrapyramidal adverse effects. He was not allowed to smoke in the hospital environment and had no significant change in body weight.

On 8 March 2019, with the clinical picture resembling clozapine toxicity, clozapine plasma level was checked and found to be grossly elevated at $3090 \mu \mathrm{g} / \mathrm{L}$ (Table 2). Dosage of clozapine was reduced from $300 \mathrm{mg}$ twice daily to $100 \mathrm{mg}$ in the morning and $150 \mathrm{mg}$ at night; dosage of other medications remained unchanged. He no longer appeared sedated and had no hypersalivation or extrapyramidal adverse effects. He had slight improvement in bowel opening but still needed laxatives. On 3 April 2019, clozapine plasma level reduced to $573 \mu \mathrm{g} / \mathrm{L}$ (Table 2). By mid-April 2019, his neutrophil count normalised but monocyte count remained elevated (Table 1).

\section{Discussion}

Clozapine plasma level is associated with clinical 
Table 1. Blood test results of patients

\begin{tabular}{|c|c|c|c|c|}
\hline \multirow[t]{2}{*}{ Blood test parameter } & \multicolumn{3}{|c|}{ Date } & \multirow[t]{2}{*}{ Reference range } \\
\hline & 13 January 2019 & 1 March 2019 & 18 April 2019 & \\
\hline White blood cell count, $\times 10^{9} / \mathrm{L}$ & $16.6 \mathrm{H}$ & $12.7 \mathrm{H}$ & 10.3 & $3.9-10.7$ \\
\hline Neutrophil, $\times 10^{9} / \mathrm{L}$ & $11.7 \mathrm{H}$ & $8.6 \mathrm{H}$ & 6.1 & $2.1-7.8$ \\
\hline Lymphocyte, $\times 10^{9} / \mathrm{L}$ & 1.7 & 1.9 & 2.3 & $1.2-3.4$ \\
\hline Monocyte, $\times 10^{9} / \mathrm{L}$ & $2.7 \mathrm{H}$ & $1.8 \mathrm{H}$ & $1.5 \mathrm{H}$ & $0.1-0.8$ \\
\hline Eosinophil, $\times 10^{9} / \mathrm{L}$ & 0.4 & 0.4 & 0.4 & $<0.45$ \\
\hline Basophil, $\times 10^{9} / \mathrm{L}$ & 0.1 & 0.1 & 0.1 & $<0$ \\
\hline
\end{tabular}

Table 2. Clozapine dosages and plasma levels

\begin{tabular}{|lcc|}
\hline Date & $\begin{array}{c}\text { Clozapine } \\
\text { dosage }\end{array}$ & $\begin{array}{c}\text { Clozapine plasma } \\
\text { level (reference } \\
\text { range, 350-600 } \boldsymbol{\mu g} / \mathrm{L} \text { ) }\end{array}$ \\
\hline 8 March 2019 & $600 \mathrm{mg} /$ day & $3090 \mu \mathrm{g} / \mathrm{L}$ \\
\hline 3 April 2019 & $250 \mathrm{mg} /$ day & $573 \mu \mathrm{g} / \mathrm{L}$ \\
\hline
\end{tabular}

response. ${ }^{1,3}$ The lower limit of clozapine levels for effective treatment is generally agreed to be $350 \mu \mathrm{g} / \mathrm{L}$, but the upper limit is less clear. The risk of seizure increases from $600 \mu \mathrm{g} / \mathrm{L}$ onwards, and $1000 \mu \mathrm{g} / \mathrm{L}$ is the threshold beyond which risks of treatment outweigh its benefits..$^{1-3}$ Adverse effects of clozapine include sedation, seizure, delirium, hypotension, and tachycardia. ${ }^{1}$

There is evidence linking infection with elevated clozapine levels. ${ }^{2}$ The underlying mechanism is thought to be due to release of inflammatory mediators (interleukin-6, tumour necrosis factor- $\alpha$, interferon, and C-reactive protein) that reduce the activity of enzyme CYP1A2 up to $90 \%$. This in turn inhibits the metabolism of clozapine into norclozapine and raises plasma clozapine levels. ${ }^{4}$ In addition, clozapine increases the risk of pneumonia and sepsis, possibly secondary to sedation, sialorrhea, and aspiration. $^{5}$

Our patient had been taking a stable dose of clozapine for $>2$ months with satisfactory tolerability. Although the underlying microorganism could not be identified and his fever subsided quickly, he probably had urinary tract infection, based on clinical signs and symptoms and the increased neutrophil count. Adverse effects of clozapine started to worsen progressively 1 to 2 weeks after the suspected infection. This prompted the checking of clozapine level, which turned out to be grossly elevated.
Dosage of clozapine was then reduced, and clozapine plasma level returned to normal range after 1 month, with adverse effects resolved. Apart from infection, we could not identify other causes such as drug-drug interactions or changes in physical condition. Nonetheless, the association between infection and elevated clozapine level remains a postulation, because of the lack of clozapine level before the onset of infection for comparison, inability to yield a microorganism in laboratory investigations, and substantial time lag between suspected infection and checking of clozapine level.

Monitoring of clozapine plasma level remains uncommon in Hong Kong, probably owing to the difficulty in interpretation and cumbersome logistics. This case report highlights the importance of checking clozapine levels in patients presenting with worsening adverse effects while on a stable dose of clozapine. Infection may be a potential cause of elevation in clozapine level or even clozapine toxicity. Other potential causes include drug-drug interactions, liver failure, and substantial drop in body weight. ${ }^{1-3}$ Further study is warranted to establish an association between infection and elevated clozapine level and to elucidate the underlying mechanisms.

\section{References}

1. Stark A, Scott J. A review of the use of clozapine levels to guide treatment and determine cause of death. Aust N Z J Psychiatry 2012;46:816-25. Crossref

2. Clark SR, Warren NS, Kim G, Jankowiak D, Schubert KO, Kisely S, et al. Elevated clozapine levels associated with infection: a systematic review. Schizophr Res 2018;192:50-6. Crossref

3. Bell R, McLaren A, Galanos J, Copolov D. The clinical use of plasma clozapine levels. Aust N Z J Psychiatry 1998;32:567-74. Crossref

4. Aitken AE, Richardson TA, Morgan ET. Regulation of drugmetabolizing enzymes and transporters in inflammation. Annu Rev Pharmacol Toxicol 2006;46:123-49. Crossref

5. Hung GC, Liu HC, Yang SY, Pan CH, Liao YT, Chen CC, et al. Antipsychotic reexposure and recurrent pneumonia in schizophrenia: a nested case-control study. J Clin Psychiatry 2016;77:60-6. Crossref 